\title{
Chronic intrahepatic cholestasis in sickle cell disease requiring exchange transfusion
}

\author{
A O'Callaghan, S G O’Brien, M Ninkovic, G P Butcher, C S Foster, J R F Walters, \\ I A G Roberts
}

\begin{abstract}
A 15 year old boy with sickle cell disease developed intrahepatic cholestasis. A course of exchange transfusion successfully corrected the extreme hyperbilirubinaemia over one year. Upon stopping the exchange transfusion programme the hyperbilirubinaemia relapsed but transfusion was effective when reinstituted. (Gut 1995; 37: 144-147)
\end{abstract}

Keywords: Sickle cell disease, intrahepatic cholestasis, hyperbilirubinaemia.

Intrahepatic cholestasis with extreme hyperbilirubinaemia may occasionally be found in sickle cell disease. Previous reports ${ }^{1-7}$ are of a benign self limiting disease lasting a few weeks or of a rapidly fatal fulminant hepatic failure. We now report a patient with a chronic cholestatic illness requiring exchange transfusion for over two years.

\section{Case report}

A 15 year old United Kingdom resident boy, born in Ghana, with known sickle cell disease, presented in August 1991 with a three week history of painless jaundice associated with pale stools, dark urine, and severe pruritus. $\mathrm{He}$ also reported anorexia, weight loss, and lethargy. He had become unwell while on holiday in Ghana where he was treated for presumed malaria despite having taken recommended prophylaxis.

Sickle cell disease was diagnosed at age 2 years. Gall stones were first shown at age 10 years when he presented with abdominal pain. He suffered two episodes of sickle chest syndrome in the previous five years, both treated with single exchange transfusions. He had no other acute crises. His steady state investigations were: haemoglobin $9.5 \mathrm{~g} / \mathrm{dl}$, reticulocytes $6 \%\left(180 \times 10^{9} / 1\right)$, white cell count $9 \times 10^{9} / 1$, haemoglobin electrophoresis: haemoglobin $\mathrm{S}(90 \%)$ and $\mathrm{F}(10 \%)$ only, bilirubin $125 \mu \mathrm{mol} / \mathrm{l}$ (normal $<17 \mu \mathrm{mol} / 1$ ), aspartate aminotransferase (AST) 45 IU/1 (normal 3-35 IU/1), alkaline phosphatase 340-420 IU/l (normal 50-500 IU/1).

On presentation he was febrile with a temperature of $38^{\circ} \mathrm{C}$. He was deeply jaundiced. The liver edge was palpable $8 \mathrm{~cm}$ below the costal margin. There were no signs of liver failure or stigmata of chronic liver disease.

Investigations showed: bilirubin $1500 \mu \mathrm{mol} / \mathrm{l}$, $64 \%$ conjugated, AST $220 \mathrm{IU} / 1$, alkaline phosphatase $378 \mathrm{IU} / \mathrm{h}$, albumin $42 \mathrm{~g} / \mathrm{l}$. Haemoglobin
$9 \cdot 5 \mathrm{~g} / \mathrm{dl}$, reticulocytes $5 \cdot 4 \%\left(153 \times 10^{9} / 1\right)$, white blood cell count $14.5 \times 10^{9} / 1$ (70\% neutrophils), platelets $503 \times 10^{9} / 1$, prothrombin time 34 seconds (control 15 seconds), activated partial thromboplastin time 55 seconds (control 45 seconds), thrombin time 35 seconds (control 19 seconds), $C$ reactive protein $8 \mathrm{mg} / 1$ (normal $<2$ ). Blood smears showed no malarial parasites and repeated blood cultures grew no organisms. Serological tests for hepatitis A, B, and C, Epstein-Barr virus, cytomegalovirus, and toxoplasma was negative. No autoantibodies were detected. An ultrasound examination showed gall stones in a contracted gall bladder, but no dilatation of intra or extrahepatic bile ducts. Endoscopic retrograde cholangiopancreatography confirmed normal appearances of hepatic and common bile ducts.

While investigations were in progress he was treated with broad spectrum antibiotics and vitamin $\mathrm{K}$, which corrected the coagulopathy. There was an initial improvement, the serum bilirubin falling to $1000 \mu \mathrm{mol} / 1$ and AST to $40 \mathrm{IU} / 1$ but the downward trend was not sustained. After three weeks the serum bilirubin was static at $900-1000 \mu \mathrm{mol} / \mathrm{l}$ and the AST had risen to $505 \mathrm{IU} / 1$ with an alkaline phosphatase of 351 IU/1. No new clinical signs emerged (that is, he continued to have painless jaundice together with pale stools and dark urine) and specifically there were no signs of liver failure. His appetite was poor and he did not regain his lost weight. He continued to receive parenteral vitamin $\mathrm{K}$ to correct his prothrombin time. His albumin fell to $33 \mathrm{~g} /$ l. Plugged liver biopsy was performed under ultrasound guidance. Portal tracts were moderately extending by an increase in fibrous tissue, which was expanding into the adjacent hepatic parenchyma. The presence of increased amounts of copper and copper associated protein in hepatocytes in Rappaport Zone 1 was confirmed by rhodanine and orceine staining, respectively. Moderate hyperplasia of hepatic parenchymal cells with ballooning of cytoplasm, prominent diffuse intracanalicular cholestasis, and sinusoidal dilatation (Fig 1) was present throughout all zones. Kupffer cells were prominent and hyperplastic. In some regions of the parenchyma there was regional collapse of the reticular architecture suggesting previous focal confluent necrosis. Increased deposition of iron within reticuloendothelial cells, including Kupffer cells, was confirmed by Perl's staining. These appearances were strongly in favour of chronic cholestasis associated with longterm haemochromatosis secondary to haemolysis.

Before liver biopsy, an exchange transfusion was carried out. There was a dramatic 


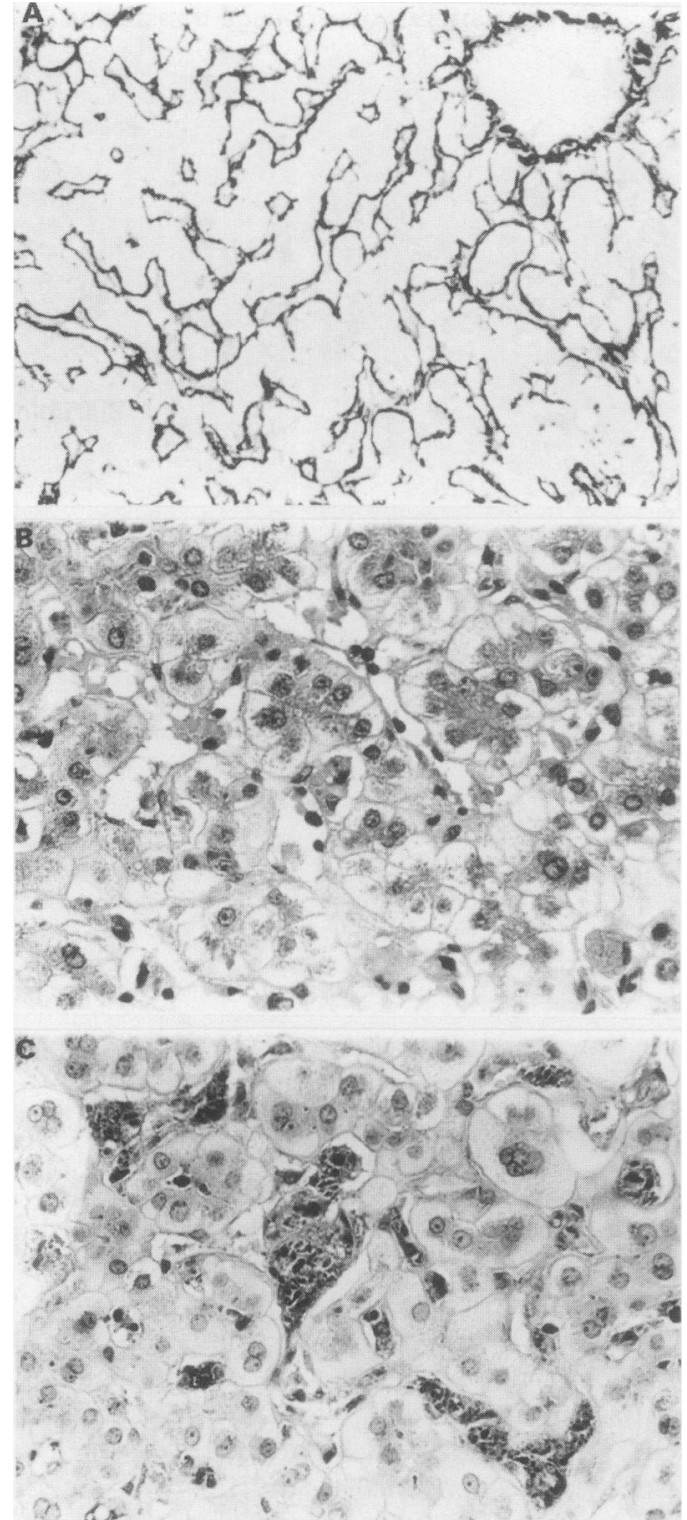

Figure 1: (A) Reticulin stain of liver showing irregular hepatocyte plates with focal parenchymal cell regenerative hyperplasia (original magnification $\times 150$ ). (B) General appearance of hepatic parenchymal zone I in which hepatocytes are oedematous, swollen, and hyperplastic with rosette formation. Adjacent sinusoids are dilated and contain small amounts of tissue debris (haematoxylin and eosin, original magnification $\times 3000$ ). (C) Hepatic parenchymal zone III containing focal collections of hyperplastic Kupffer cells within dilated sinusoids. Intrasinusoidal and intracanalicular aggregates of cholestasis are present throughout this haematoxylin and eosin zone, original magnification $\times 300$ ).

response with bilirubin falling to $180 \mu \mathrm{mol} / 1$ and AST to 369 IU/l. Over the next few weeks the jaundice again gradually worsened and he again complained of pale stools and dark urine. By 40 days after admission his bilirubin had reached $1052 \mu \mathrm{mol} / 1$ with an AST of $369 \mathrm{IU} / \mathrm{l}$, alkaline phosphatase of 586 IU/h, stable haemoglobin of $9.4 \mathrm{~g} / \mathrm{dl}$, and a prothrombin time of 14.7 seconds. He was therefore started on a regular exchange transfusion programme to maintain the haemoglobin $\mathrm{S}$ concentration at less than $20 \%$. After this his clinical condition returned to normal, bilirubin concentrations remained at less than $200 \mu \mathrm{mol} / \mathrm{l}$, the AST returned to steady state values (less than $50 \mathrm{IU} / \mathrm{l})$, serum albumin increased to 40-45 $\mathrm{g} / \mathrm{l}$, and the prothrombin time remained normal without vitamin $\mathrm{K}$. His weight, which had dropped by $5 \mathrm{~kg}$ to the 25 th centile over the three months of his acute illness, began to rise and had returned, without nutritional supplementation, to the 75 th centile after nine months. Liver biopsy at eight months showed histological recovery.

About one year after initial presentation, after a period of erratic attendance at hospital, his haemoglobin $\mathrm{S}$ concentration rose to $56 \%$. His original symptoms of fever, severe jaundice, right upper quadrant pain associated with dark urine, pale stools, and hepatomegaly returned. His only treatment was prophylactic penicillin $\mathrm{V}$ and folic acid. Biochemical profile showed raised bilirubin at $736 \mu \mathrm{mol} / \mathrm{l}$; AST 73 IU//; alkaline phosphatase 391 IU/1. The prothrombin time was prolonged at 18 seconds but the haemoglobin was stable at $9.6 \mathrm{~g} / \mathrm{dl}$. Although his AST continued to rise, reaching a peak of $430 \mathrm{IU} / 1$, again this relapse rapidly responded to exchange transfusion (Fig 2 ). He continues, nearly three years after presentation to require regular exchange transfusions to control the hyperbilirubinaemia.

\section{Discussion}

Hyperbilirubinaemia in sickle cell disease is a common finding. ${ }^{1-5}$ The range of steady state bilirubin values is wide, $25-110 \mathrm{umol} / \mathrm{l}$, and typically doubles during crisis. ${ }^{5}$ Extreme hyperbilirubinaemia in these patients can be a feature of a number of complicating conditions particularly viral hepatitis, ${ }^{6-9}$ biliary tract obstruction, and hepatic sickle cell crisis. ${ }^{34}$ In our patient there was no evidence to support any of these diagnoses.

Hepatic sickle cell crisis is a transient form of intrahepatic obstruction, which presents acutely with right upper quadrant pain, hepatic enlargement, fever, and jaundice. It runs a short clinical course settling spontaneously in three to seven days and is often seen in combination with other clinical and haematological features of sickle cell crisis. ${ }^{4}$ This pattern of acute sickle cell crisis contrasts considerably with our patient whose symptoms persisted for three months and could only be controlled by intensive exchange transfusion every two weeks. Indeed his symptoms returned when, after erratic attendance, his haemoglobin S concentration rose to $56 \%$. Our patient also differs from the more commonly observed hepatic crisis in that he had no other features of an acute sickle cell crisis and in particular no pain or evidence of increased haemolysis as shown by a stable haemoglobin and reticulocyte count during such episodes. The duration and slow onset of the extreme hyperbilirubinaemia and the absence of typical features of painful sickle cell crises together make it much more probable that this represented chronic intrahepatic cholestasis rather than recurrent episodes of sickle cell crisis.

A distinct clinical presentation is that of sickle cell intrahepatic cholestasis, which is a syndrome defined by characteristic histological features: intracanalicular cholestasis, sinusoidal dilatation, Kupffer cell hyperplasia, and 

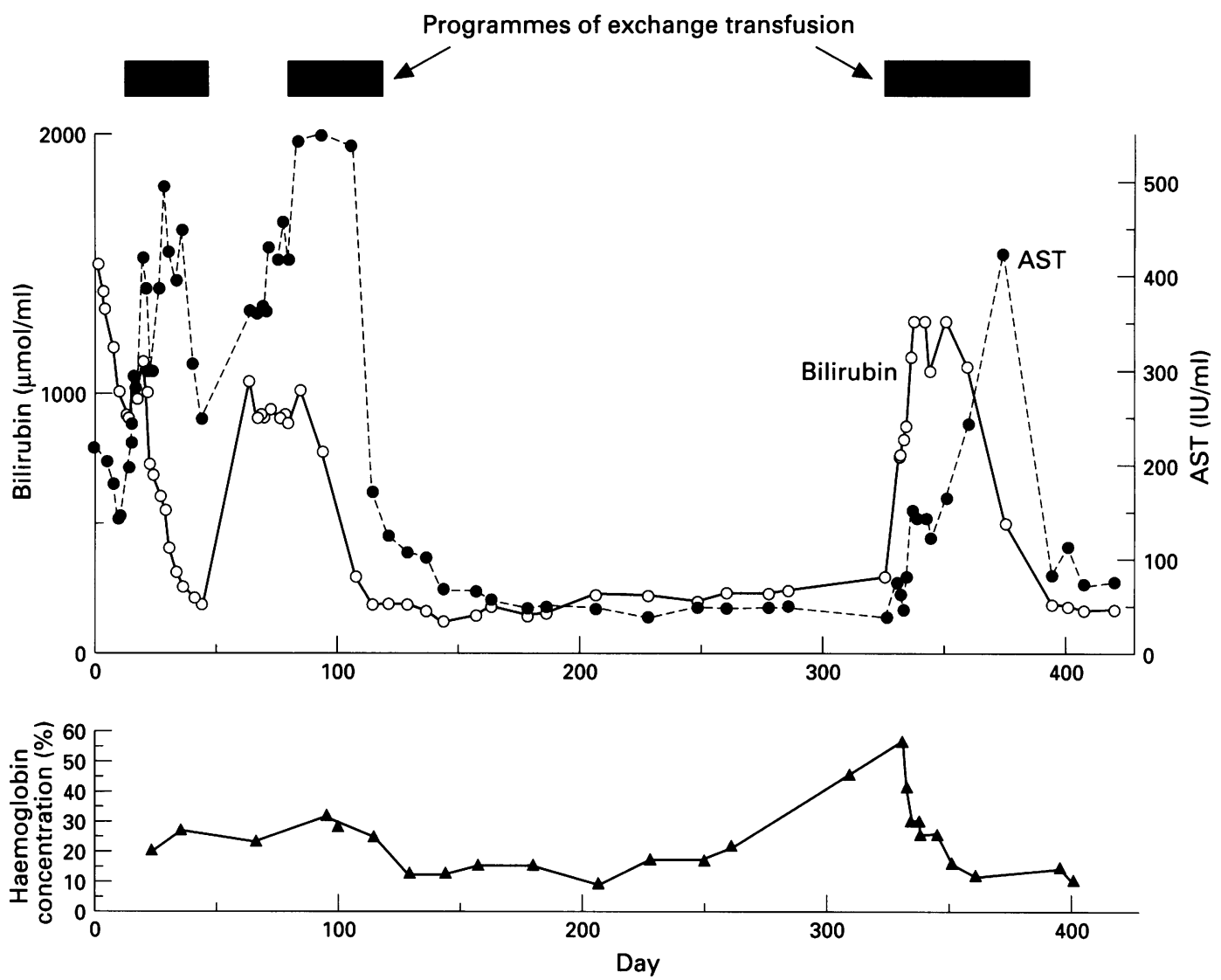

Figure 2: Changes in bilirubin, AST and haemoglobin $S$ values in relation to programmes of exchange transfusion.

erythrophagocytosis. The postulated pathogenesis is that sickled red blood cells plug hepatic sinusoids causing vascular stasis leading to local hypoxia. The resultant ballooning of hepatocytes causes a direct back pressure effect, which gives rise to intracanalicular cholestasis. Kupffer cells and sinusoidal macrophages then hypertrophy in response to presence of sickled cells and associated cellular debris. ${ }^{1-4}$ The absence of sickled red blood cells in biopsy specimens from patients with sickle cell disease may be explained by the accepted practice of performing exchange transfusion before invasive procedures.

Some previous reports of intrahepatic cholestasis were associated with a high death rate, (seven of the first eight reported cases), the cause of death being fulminant hepatic failure or bleeding diathesis, or both. ${ }^{2410}$ The characteristic histological pattern was described on examination of necropsy specimens. Partial exchange transfusion was first used in this situation in 1980 and it proved to be a life-saving intervention. Signs of liver failure regressed in 48 hours and biochemical resolution was almost complete within one week. ${ }^{10}$

In contrast with the above severe clinical picture a benign course of extreme hyperbilirubinaemia has been reported. ${ }^{511}$ In a group of children, who had few signs and symptoms and unremarkable liver enzyme activities, bilirubin values ranging from 347 to $979 \mu \mathrm{mol} / 1$ were recorded. In all, the condition was self limiting with return to steady state values within two to eight weeks and liver function tests remained normal on longterm follow up. ${ }^{11}$ Biopsy was not performed in any of these cases so histological proof of a similar process is not available. A benign self limiting cholestatic syndrome has also been seen in association with oxymethalone administration, phenothiazine ingestion, and pregnancy in sickle cell patients. ${ }^{5}$

In the presence of typical histology and having excluded other possible secondary causes, 8912 the hepatic dysfunction seen in this patient seems to be caused by sickle cell intrahepatic cholestasis. The clinical, biochemical, and histological recovery in response to intensive exchange transfusion regimen supports this, as does the relapse in conjunction with a rising haemoglobin $S$ concentration.

We have described an unusual case of prolonged intrahepatic cholestasis in a patient with sickle cell disease characterised by extreme hyperbilirubinaemia. We believe that it is important to recognise this condition as successful treatment requires intensive and maintained exchange transfusion to return liver function to steady state. This sets it apart from other causes of pronounced hyperbilirubinaemia in sickle cell disease, which are transient and may be either benign, usually in children, or associated with fulminant hepatic failure and early death.

1 Green TW, Conley CL, Berthrong M. The liver in sickle cell anemia. Fohn Hopkins Med F 1953; 92: 99-127.

2 Owen DM, Aldridge JE, Thompson RB. An unusual hepatic sequela of sickle cell anemia: a report of five cases. Am F Med Sci 1965; 249: 175-85.

3 Rosenblate HJ, Einstein R, Holmes AW. The liver in sickle cell anemia: a clinical-pathological study. Arch Pathol 1970; 90: 235-45.

4 Sheehy TW. Sickle cell hepatopathy. South Med F 1977; 70: 533-8. 
5 Johnson CS, Omata M, Tong MJ, Simmons JF, Weiner J, Tatter D. Liver involvement in sickle cell disease. Medicine 1985; 64: 349-56.

6 Hargrove MD. Marked increase in serum bilirubin in sickle cell anemia. A report of six patients. Dig Dis $1970 ; 15$ 437-42.

7 Yohannan MD, Arif M, Ramia S. Aetiology of icteric hepatitis and fulminant hepatic failure in children and the possible predisposition to hepatic failure by sickle cell disease. Acta Paediatre Scand 1990; 79: 201-5.

8 Luther R, Mwakyusa D, Milner PF. Histopathologic features of liver biopsy specimens in sickle cell disease. features of liver biopsy specimens in sich
Arch Pathol Lab Med 1988; 112: 290-4.
9 Omata M, Johnson CS, Tong M, Tatter D. Pathological spectrum of liver diseases in sickle cell disease. Dig Dis Sci 1986; 31: 247-56.

10 Sheedy TW, Law DE, Wade BH. Exchange transfusion for sickle cell intrahepatic cholestasis. Arch Intern Med 1980 140: 1364-6.

11 Buchanan GR, Glader BE. Benign course of extreme hyperbilirubinemia in sickle cell anemia: analysis of six cases. f Pediatr 1977; 91: 21-4.

12 Comer GM, Ozick LA, Sachdev RK, Kumar S, Taunk JL, Smith JA, et al. Transfusion-related chronic liver disease in sickle cell anemia. Am $\mathcal{J}$ Gastroenterol 1991; 86: 1232-4. 